\title{
Perancangan Sistem Informasi Akuntansi Persediaan Barang Dagang Berbasis SAK EMKM
}

\author{
Hery Dwi Yulianto ${ }^{1}$, Dyan Fachri Maulana ${ }^{2}$ \\ ${ }_{1,2}$ Program Studi Komputerisasi Akuntansi, Universitas Komputer Indonesia, Bandung, Jawa Barat, Indonesia \\ Email: hery.dwi.yulianto@email.unikom.ac.id
}

\begin{abstract}
The purpose of this study is to make a design of accounting information systems for merchandise inventory at the Cireng Cinta Shop with a website-based and SAK EMKM, where it is expected that the development of the system can provide an overview of the proper application of the merchandise inventory accounting information system. Currently Cireng Cinta Shop still uses manual processing throughout, where when ordering products the product must come to the seller's place to place an order or via SMS or WA, after that when the collection is not given proof of payment that should be evidence for later reporting. Inventory management is still manually which is not taken into account. Therefore, with the design of an accounting information system for merchandise inventory to facilitate application development in accordance with $S A K E M K M$ and activities. The method used in this research is descriptive method and also survey, where by conducting a direct survey at the site of the activity makes it easy to see firsthand the shortcomings and potential that might be developed further. The unit of analysis examined in this study is the Cireng Cinta Shop, the population studied is the inventory report from January-April 2020. The results of this study are expected to be able to find out about merchandise inventory information systems, as well as design systems that will be applied to companies. The design process of making ERD, context diagrams, program menu structures, account codes, general journals, and merchandise inventory cards are required by the company. With the development of this system, it will facilitate the process of integrating company problems with future application design.
\end{abstract}

Keywords: Accounting Information Systems, SAK EMKM Merchandise Inventory, Manufacturing, Financial Statements

\begin{abstract}
ABSTRAK
Tujuan dari penelitian ini adalah membuat suatu perancangan sistem informasi akuntansi persediaan barang dagangan pada Toko Cireng Cinta dengan berbasis website dan SAK EMKM, dimana diharapkan dengan dibangunnya sistem tersebut dapat memberikan gambaran aplikasi sistem informasi akuntansi persediaan barang dagang yang tepat. Saat ini Toko Cireng Cinta masih menggunakan pengolahan keseluruhsan secara manual, dimana saat melakukan pemesanan produk harus mendatangi tempat penjual untuk melakukan pemesanan atau melalui via SMS atau WA, setelah itu saat pengambilan tidak diberi bukti pembayaran yang seharusnya itu bisa menjadi bukti untuk nanti pembuatan laporan. Pengelolaan persediaan pun masih secara manual dan belum menggunakan standar akuntansi yang ada. Maka dari itu dengan dibuatkannya perancangan sistem informasi akuntansi persediaan barang dagangan ini untuk memudahkan pengembangan aplikasi sesuai dengan SAK EMKM dan kegiatan perusahaan. Medode yang digunakan dalam penelitian ini adalah metode deskriptif dan juga survey, dimana dengan melakukan survey langsung pada tempat kegiatan memudahkan untuk melihat langsung kekurangan dan potensi yang mungkin dapat dikembangan lebih lanjut. Unit analisis yang diteliti dalam penelitian ini adalah Toko Cireng Cinta, populasi yang diteliti adalah laporan persediaan dari mulai Januari-April 2020. Hasil dari penelitian ini diharapkan bisa mengetahui tentang sistem informasi persediaan barang dagang, juga membuat perancangan sistem yang akan diterapkan pada perusahaan. Proses perancangan dari pembuatan ERD, Diagram Konteks, Struktur menu program, kode akun, jurnal umum, dan kartu persediaan barang dagangan diperlukan oleh perusahaan. Dengan terbangunnya sistem ini akan memudahkan proses integrasi permasalahan perusahaan dengan perancangan aplikasi kedepannya.
\end{abstract}

Kata Kunci: Sistem Informasi Akuntansi, Persediaan Barang Dagang SAK EMKM, Manufaktur, Laporan Keuangan 


\section{Pendahuluan}

Kemajuan perkembangan teknologi di zaman ini sudah semakin maju, apabila tidak bisa mengikuti perkembangan zaman saat ini maka, akan selangkah tertinggal dari orang lain. Dalam perkembangan teknologi ini maka seorang mahasiswa dituntut untuk selalu bisa beradaptasi mengembangkan kemampuan dengan perkembangan zaman. Perkembangan informasi saat ini begitu cepat maka diharuskan suatu sistem bisa mengelola data informasi tersebut secara tepat, cepat, dan akurat untuk menghasilkan suatu laporan yang diperlkukan suatu persuahaan. Internet menjadi sebuah instrument yang mendukung perkembangan zaman, yang mengubah kehidupan sosial dan ekonomi menjadi lebih baik, meskipun dengan begitu pula muncul masalah baru dimana terjadinya banyak kecurangan maupun penipuan yang disebabkan perkembangan internet.[1]

Beberapa standar akuntansi yang diterapkan di Indonesia meliputi PSAK-IFRS, SAK-ETAP, PSAK-Syariah, dan SAP. Standar Akuntansi Keuangan Entitas Mikro, Kecil, dan Menengah (SAKEMKM) merupakan Standar Akuntansi Keuangan untuk Entitas Tanpa Akuntansi Publik (SAKETAP). Standar akuntansi keuangan ini mengatur transaksi yang umum dilakukan oleh UMKM yaitu menyusun laporan keuangan yang berbasis akrual. Berdasarkan kegiatan dan pengukurannya murni menggunakan biaya historis, sehingga UMKM cukup mencatat aset, liabilitas, ekuitas, bebanbeban (expenses), dan pendapatan (income) sebesar biaya perolehannya.[2]

Industri makanan pada umumnya berkembang dengan mengembangkan kapitas produksi produk yang dihasilkan dengan menambah jumlah mesin, juga menambah sumber daya manusia agar kapasitas produksi dari produk meningkat[3]. usaha yang dilakukan para industri makanan pada umumnya kebanyakan masih di UMKM dimana menurut data dari Kementerian Koperasi dan Usaha Mikro, Kecil, dan Mengengah di Indonesia pada tahun 2012 yaitu mencapai 99,99\% dari jumlah unit usaha di Indonesia[4]. Juga UMKM menjadi tempat penyerapan tenaga kerja di Indonesia sebesar 97,16\%, UMKM juga menjadi pemasukan untuk Produk Domestik Bruto (PDB) sebesar 59,08\% dan pembayaran pajak sebesar Rp. 4.869.568.100.000.000. Dengan banyaknya UMKM tersebut membuat harusnya perusahaan manufaktur menjadi lebih berpusat kepada pelanggan dan inovasi, dengan begitu masyarakat akan menerima produk yang lebih sesuai dengan keinginan mereka walaupun banyaknya persaiangan[5].

Sistem banyak dibutuhkan dalam setiap perusahaan, seperti untuk bagian keuangan dan pemasaran. Agar lebih memudahkan untuk pembuatan suatu laporan keuangan yang diharapkan perusahaan, dengan menggunakan sistem kemudahan dalam membuat laporan akan terasa lebih, juga hasil yang didapatkan menjadi lebih akurat apabila menggunakan sistem juga meminimalisir kecurangan dalam suatu kejadian. Juga pada bagian persediaan barang dagangan dimana dengan menggunakan sistem kita bisa dengan cepat melihat kondisi seberapa banyak barang yang tersedia untuk di jual. Tetapi pada perusahaan yang peneliti teliti saat ini setiap kegiatan masih dilakukan secara manual dimana pencatan hasil penjualan, pemesanan, dan pengolahan persediaan barang dagangan masih tidak maksimal. Dimana manajemen persediaan memainkan peran penting dalam setiap perusahaan karena setiap sistem persediaan yang tidak efektif akan mengakibatkan hilangnya pelanggan dan penjualan. [6] Penulis disini melakukan penelitian agar setiap kegiatan yang dilakukan perusahaan lebih terorganisir dan bisa dipantau secara berkala oleh pemilik juga memudahkan untuk melakukan pencatatan persediaan barang dagangan, sehingga tidak ada kesalahan dan kekeliruan terhadap barang yang tersedia dan sudah terjual.

Berdasarkan masalah tersebut untuk membantu kinerja dalam pencatatan persediaan barang dagangan, penulis akan merancangkan sebuah sistem informasi berbasis web menggunakan PHP MySql yang diharapkan dapat meminimalisir penggunaan dokumen dan penulis tertarik mengambil judul "Perancangan Sistem Informasi Akuntansi Persediaan Barang Dagang Berbasis SAK EMKM". 


\section{Kerangka Teoritis \\ Perancangan}

Definisi perancangan "Perancangan adalah suatu proses untuk membuat dan mendesain sistem yang baru." [7] Definisi lain dari perancangan "Perancangan adalah suatu kemampuan untuk membuat beberapa alternatif pemecahan masalah". [8] Berdasarkan definisi di atas penulis menyimpulkan bahwa, perancangan adalah kemampuan untuk membuat alternatif pemecahan masalah dengan membuat dan mendesai system baru untuk menyelesaikan masalah suatu perusahaan.

\section{Sistem}

Definisi sistem "Sistem adalah suatu kumpulan atau himpunan dari unsur, komponen, variabel yang terorganisasi, saling berinteraksi, saling tergantung sama lain dan terpadu". [9] Definisi lain dari sistem "Inti sistem adalah subsistem atau gabungan subsistem yang sedang berlangsung dalam loop proses yang mempunyai pengaruh paling dominan".[10] Berdasarkan definisi diatas penulis menyimpukan bahwa, sistem adalah kumpulan unusr komponen atau subsistem yang saling berinteraksi untuk mencapai suatu tujuan.

\section{Perancangan Sistem}

Pengertian perancangan sistem adalah penentuan proses dan data yang diperlukan oleh sistem baru. Tujuan dari perancangan sistem adalah untuk memenuhi kebutuhan pemakai sistem serta untuk memberikan gambaran yang jelas dan rancang bangun yang lengkap [11]. Sedangkan "perancangan sistem dapat didefinisikan sebagai penggambaran, perencanaan, dan pembuatan sketsa atau pengaturan dari beberapa elemen terpisah ke dalam satu kesatuan yang utuh dan berfungsi.’'[12]

\section{Informasi}

Definisi informasi "Informasi adalah data yang diolah menjadi bentuk yang lebih berguna dan lebih berarti bagi penerimanya." [13] Definisi lain dari informasi "Informasi adalah hasil pengolahan data yang memberikan arti dan manfaat". [14] Berdasarkan definisi diatas penulis menyimpulkan bahwa, informasi adalah kumpulan data yang telah diolah dan dapat memberikan manfaat bagi setiap penerimanya.

\section{Sistem Informasi}

Definisi sistem informasi:

"Sistem informasi adalah suatu sistem di dalam suatu organisasi yang mempertemukan pengolahan transaksi harian yang mendukung fungsi operasi organisasi yang bersifat kegiatan strategi dari suatu organisasi untuk dapat menyediakan laporan-laporan yang diperlukan oleh pihak tertentu." $[9]$

Definisi lain dari sistem informasi adalah "kumpulan dari sub-sub sistem baik phisik yang saling berhubungan satu sama lain dan bekerja sama secara harmonis untuk mencapai satu tujuan yaitu mengelola menjadi informasi yang berguna". [15] Bedasarkan definisi diatas penulis dapat menyimpulkan bahwa, sistem informasi adalah sistem yang bertugas mengumpulkan, memproses data, mengolah data menjadi informasi yang bermanfaat juga menghasilkan suatu laporan-laporan yang diperlukan oleh pihak tertentu. 


\begin{abstract}
Akuntansi
Definisi akuntansi adalah "Suatu sistem dan teknologi yang mempelajari seni pencatatan, pengklasifikasian, pengikhtisaran, dan pelaporan keuangan dari kejadian transaksi bisnis menjadi laporan keuangan yang dibutuhkan oleh para pengguna". [15] Definisi lain dari akuntansi "Akuntansi adalah suatu proses pencatatan, penggolongan, peringkasan yang menghasilkan informasi ekonomi untuk diberikan kepada pihak pengguna." [16] Berdasarkan definisi diatas penulis dapat menyimpulkan bahwa, akuntansi adalah aktifitas proses identifikasi, pencatatan, pelaporan transaksi dimenghasilkan suatu informasi keuangan berupa laporan yang bermanfaat bagi perusahaan.
\end{abstract}

\title{
Sistem Infomasi Akuntansi
}

Definisi Sistem informasi akuntansi adalah: "Sistem Informasi Akuntansi merupakan suatu komponen yang mengumpulkan, menggolongkan, mengolah, menganalisa, dan mengkomunikasikan informasi keuangan yang relevan untuk pengambilan keputusan kepada pihak luar." [17] Definisi lain sistem Informasi Akuntansi adalah "kumpulan atau grup dari sub sistem/bagian/komponen apapun baik phisik atau non phisik yang saling berhubungan satu sama lain dan bekerja sama secara harmonis untuk mengolah data transaksi yang berkaitan dengan masalah keuangan menjadi informasi keuangan." [18]

\section{Persediaan Barang Dagang}

Definisi persediaan barang dagang "Persediaan barang dagang adalah jumlah persediaan barang dagang yang ada pada akhir periode tertentu."[19] Adapun definisi lainnya adalah "persediaan barang dagang, yang merupakan barang yang dibeli untuk tujuan dijual kembali."[20] Berdasarkan pengertian diatas penulis dapat menyimpulkan bahwa persediaan barang dagang adalah persediaan barang yang akan dibeli dan dijual kembali dan diakhir periode akan dihitung jumlah akhirnya.

\section{SAK EMKM}

Standar akuntansi keuangan entitas mikro, kecil, dan menengah disusun untuk memenuhi kebutuhan pelaporan keuangan entitas mikro, kecil, dan menengah dengan acuan kepada UU No.20 Tahun 2008 dalam mendefinisikan dan memberikan rentang kuantitatif EMKM. [21] Entitas mikro, kecil, dan menengah adalah entitas tanpa akuntabilitas publik yang signifikan, sebagaimana didefinisikan dalam Standar Akuntansi Keuangan Entitas Tanpa Akuntabilitas Publik (SAK ETAP), yang memenuhi definisi dan kriteria usaha mikro, kecil, dan menengah sebagaimana diatur dalam peraturan perundang-undangan yang berlaku di Indonesia, setidaktidaknya selama dua tahun berturut-turut. Standar akuntansi EMKM yang digunakan untuk membuat perancangan sistem dari jurnal umum, buku besar, kartu persediaan, laporan persediaan barang dagang, laporan arus kas.

\section{Bentuk, Jenis, dan Bidang Perusahaan/Instansi}

Bentuk perusahaan yang diteliti adalah UMKM, jenis perusahaan yang diteliti adalah Perusahaan Manufaktur yang bergerak dibidang mengolah dari bahan baku menjadi bahan jadi dan bidang usaha yang diteliti adalah produksi makanan ringan, dimana perusahaan membuat suatu makanan yang bermanfaat dan juga bisa memberikan keuntungan dari penjualan makanan ringan tersebut.

\section{Konsep Desain Perancangan Sistem Informasi}

Pengembangan aplikasi online dapat menggunakan pendekatan web base menggunakan bahasa pemrograman PHP dan untuk pengelolaan database bisa menggunakan paket bawaan MySQL. Untuk pengguna aplikasi dipisah berdasarkan bagian meliputi kasir, produksi, dan owner. 
Setiap pengguna memiliki hak akses sesuai dengan kegiatan dan fungsinya masing-masing. Penggunaan aplikasi dimulai dari user melakukan proses login terlebih dahalu.

\section{Metode}

Metode penelitian kuantitatif yang digunakan untuk pengumpulan data sebagai bahan penelitian menggunakan metode deskriptif dan metode survei. Dimana peneliti melakukan surver untuk mendapatkan data yang diperlukan, kemudian menggambarkan menjadi rangka penelitian untuk mendapatkan solusi dari masalah yang dihadapi. Kemudian pengumpulan data dilakukan dengan melalukan wawancara dilapangan dan mengkaji referensi dari pustaka-pustaka.

Unit analisis dalam penelitian ini adalah toko Cireng Cinta yang bediri sejak 2008, populasi yang diteliti oleh peneliti adalah laporan persediaan barang yang ada di toko Cireng Cinta dari mulai Januari-April 2020. Objek penelitian dalam penelitian ini adalah untuk menjelaskan tentang perancangan sistem informasi akuntansi persediaan barang dagang. Model pengembangan sistem yang digunakan adalah metode pengembangan literasi. Dan metode perancangan sistem yang digunakan adalah metode waterfall dimana tahapan dan proses perancangan sistem secara berurutan. Pada tahap pengembangan sistem ini yang akan dilakukan adalah tahap 1 sampai tahap 3 dari 6 tahap. Tahapan tersebut meliputi: 1. Analisis (Analysis) 2. Pembuatan model sistem 3. Desain (Design) 4. Penulisan Program (Coding) 5. Pengetesan (Testing) 6. Perawatan Sistem (Maintenance) [22].

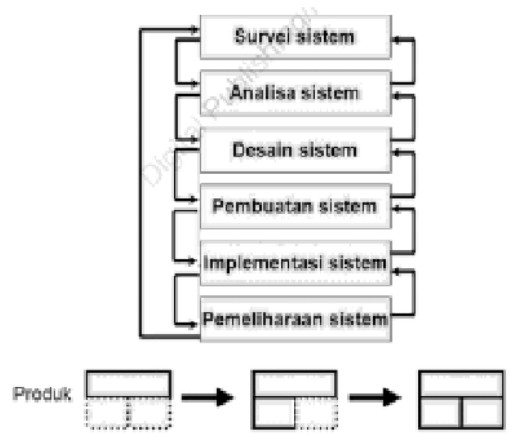

Gambar 1. Model literasi [22]

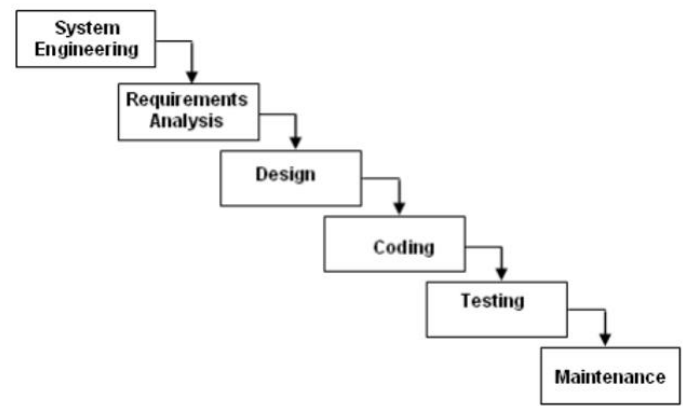

Gambar 2. Model Waterfall[21]

\section{Hasil dan Pembahasan}

\section{Perancangan Sistem Informasi Akuntansi Persediaan Barang Dagang}

\subsection{Kode Akun yang Diusulkan}

Tabel 1. Kode Akun

\begin{tabular}{|c|l|l|}
\hline Nomor Akun & Nama Akun Indonesia & \multicolumn{1}{|c|}{ Nama Akun Asing } \\
\hline $\mathbf{1 - 1 0 0}$ & Asset & Asset \\
\hline $1-110$ & Kas & Cash \\
\hline $1-120$ & Piutang Dagang & Account Receivable \\
\hline $1-130$ & Persediaan Bahan Baku & Raw Material Inventory \\
\hline $1-140$ & Persediaan Dalam Proses & Work In Process Inventory \\
\hline $1-150$ & Persediaan Barang Jadi & Finished Goods Inventory \\
\hline $\mathbf{2 - 1 0 0}$ & Kewajiban & Liabilities \\
\hline $2-110$ & Utang Lancar & Account Payable \\
\hline $\mathbf{3 - 1 0 0}$ & Modal & Equitas \\
\hline $3-110$ & Modal Pemilik & Owner Capital \\
\hline $\mathbf{4 - 1 0 0}$ & Revenue & Pendapatan \\
\hline $4-110$ & Penjualan & Sales \\
\hline $4-120$ & Harga Pokok Produksi & Cost of Goods Manufacture \\
\hline $\mathbf{5 - 1 0 0}$ & Biaya & Cost \\
\hline $5-110$ & Biaya Gaji & Factory Salary Cost \\
\hline
\end{tabular}


1.2. Dokumen Pendukung

\begin{tabular}{|c|c|}
\hline Jl. Kecamatan & $\begin{array}{l}\text { ENG CINTA } \\
\text { Rt.03 Rw.09 Kec. Cimahi Utara } \\
\text { ibabat } 40513\end{array}$ \\
\hline \multicolumn{2}{|c|}{ Bukti Pembayaran } \\
\hline Tanggal & $18 / 05 / 2020$ \\
\hline Nomor Pesanan & M-001 \\
\hline Nam Pemesan & Junaedi \\
\hline Kode Barang & CRK, CRB \\
\hline \multirow[t]{2}{*}{ Quanty } & CRK: 50 Unit \\
\hline & CRB: 50 Unit \\
\hline \multirow[t]{2}{*}{ Harga } & CRK:@Rp.700 \\
\hline & CRB:@Rp.1000 \\
\hline Total & Rp. 85.000 \\
\hline \multirow[t]{3}{*}{ Keterangan } & $\begin{array}{c}\text { Harap embawa bukti saat } \\
\text { pengambilan barang }\end{array}$ \\
\hline & da Tangan \\
\hline & Dyan \\
\hline
\end{tabular}

Gambar 3. Dokumen Bukti Pemesanan

Dokumen ini digunakan saat pembeli melakukan pembelian dan membayar pada saat mengambil barang. Dimana nantinta bukti ini akan di bawa kembali dan mendapat bukti pembayaran yang ada pada gambar 4 .

\begin{tabular}{|c|c|}
\hline $\begin{array}{r}\mathrm{C} \\
\text { Jl. Kecamatan No.14 } \\
\text { Kel }\end{array}$ & $\begin{array}{l}\text { ENG CINTA } \\
\text { Rt.03 Rw.09 Kec. Cimahi Utara } \\
\text { iibabat } 40513\end{array}$ \\
\hline \multicolumn{2}{|c|}{ Bukti Pembayaran } \\
\hline Tanggal & $18 / 05 / 2020$ \\
\hline Nomor Pesanan & M-001 \\
\hline Nam Pemesan & Junaedi \\
\hline Kode Barang & CRK, CRB \\
\hline \multirow[t]{2}{*}{ Quanty } & CRK: 50 Unit \\
\hline & CRB: 50 Unit \\
\hline \multirow[t]{2}{*}{ Harga } & CRK:@Rp.700 \\
\hline & CRB:@Rp.1000 \\
\hline Total & Rp. 85.000 \\
\hline Nominal Pembayaran & Rp.100.000 \\
\hline Sisa Pembayaran & Rp. 15.000 \\
\hline \multirow[t]{3}{*}{ Keterangan } & $\begin{array}{c}\text { Harap embawa bukti saat } \\
\text { pengambilan barang }\end{array}$ \\
\hline & da Tangan \\
\hline & Dyan \\
\hline
\end{tabular}

Gambar 4. Dokumen Bukti Pembayaran

Dalam saat pemesanan pelanggan diberi dua pilihan akan melakukan pembayaran langsung, atau pada saat pengambilan barang. Apaliba melakukan pembayaran saat pengambilan barang akan mendapat dua bukti transaksi. Dan apabila melakukan pembayaran saat pemesanan maka hanya akan mendapatkans satu bukti yaitu bukti pembayaran. 
@ is The Best: Accounting Information Systems and Information Technology Business Enterprise

ISSN: 2252-9853 (Print) | ISSN: 2656-808X (Online)

1.3. Jurnal Umum

Tabel 2. Jurnal Umum

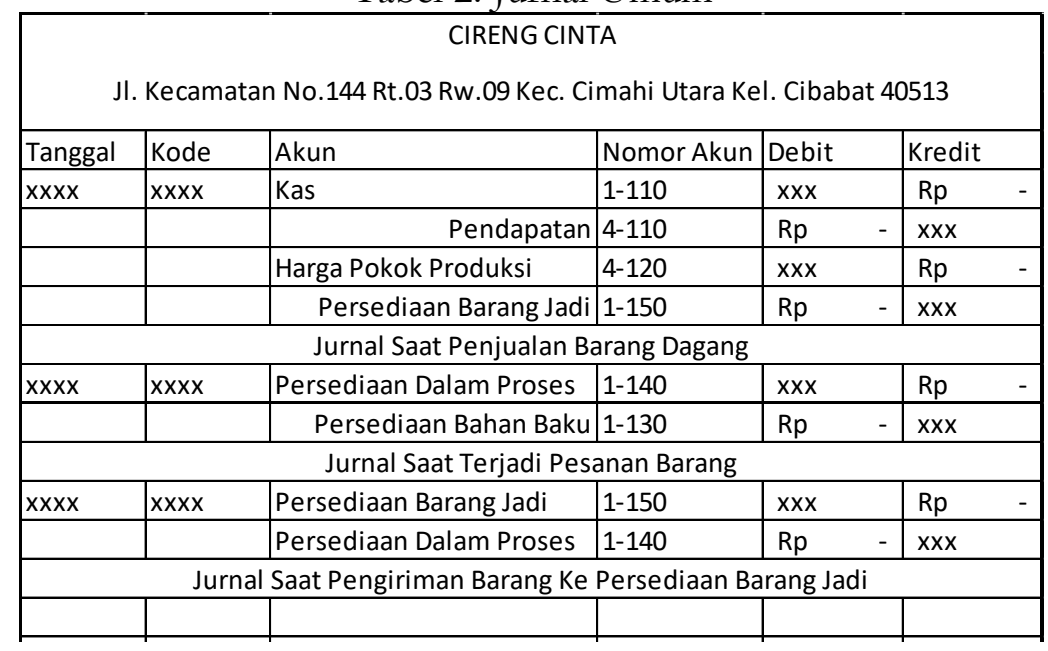

Perkiraan jurnal umum yang akan digunakan untuk membantu perusahaan dalam mengelola usahanya.

\subsection{Kartu Persediaan}

Tabel 3. Kartu Persediaan Bahan Baku

\begin{tabular}{|l}
\multicolumn{7}{|c|}{ J. Kecamatan No.144 Rt.03 Rw.09 Kec. Cimahi Utara Kel. Cibabat 40513 } \\
Kartu Persediaan Bahan Baku \\
Kode Bahan Baku
\end{tabular}

Tabel 4 Kartu Persediaan Barang Jadi CRK

\begin{tabular}{|l|l|l|}
\multicolumn{7}{|c|}{ I. Kecamatan No.144 Rt.03 Rw.09 Kec. Cimahi Utara Kel. Cibabat 40513 } \\
Kartu Persediaan Barang Jadi \\
CRK
\end{tabular}


Hery Dwi Yulianto ${ }^{1}$, Dyan Fachri Maulana ${ }^{2}$

@ is The Best: Accounting Information Systems and Information Technology Business Enterprise

ISSN: 2252-9853 (Print) | ISSN: 2656-808X (Online)

Tabel 5. Kartu Persediaan Barang Jadi CRB

\begin{tabular}{|l|l|l|l|l|l|l|}
\hline \multicolumn{7}{|c|}{ Cireng Cinta } \\
J. Kecamatan No.144 Rt.03 Rw.09 Kec. Cimahi Utara Kel. Cibabat 40513 \\
Kartu Persediaan Barang Jadi \\
Kode Barang Jadi
\end{tabular}

Pada kartu persediaan bahan baku digunakan saat penggunaan bahan baku untuk masuk ke bagain produksi pembuatan cireng, dan kemudian setelah selesai maka akan masuk ke kartu persediaan barang jadi yang nanti apabila pelanggan akan mengambil pengurangan akan terjadi dalam kartu persediaan barang jadi.

2. Flowchart

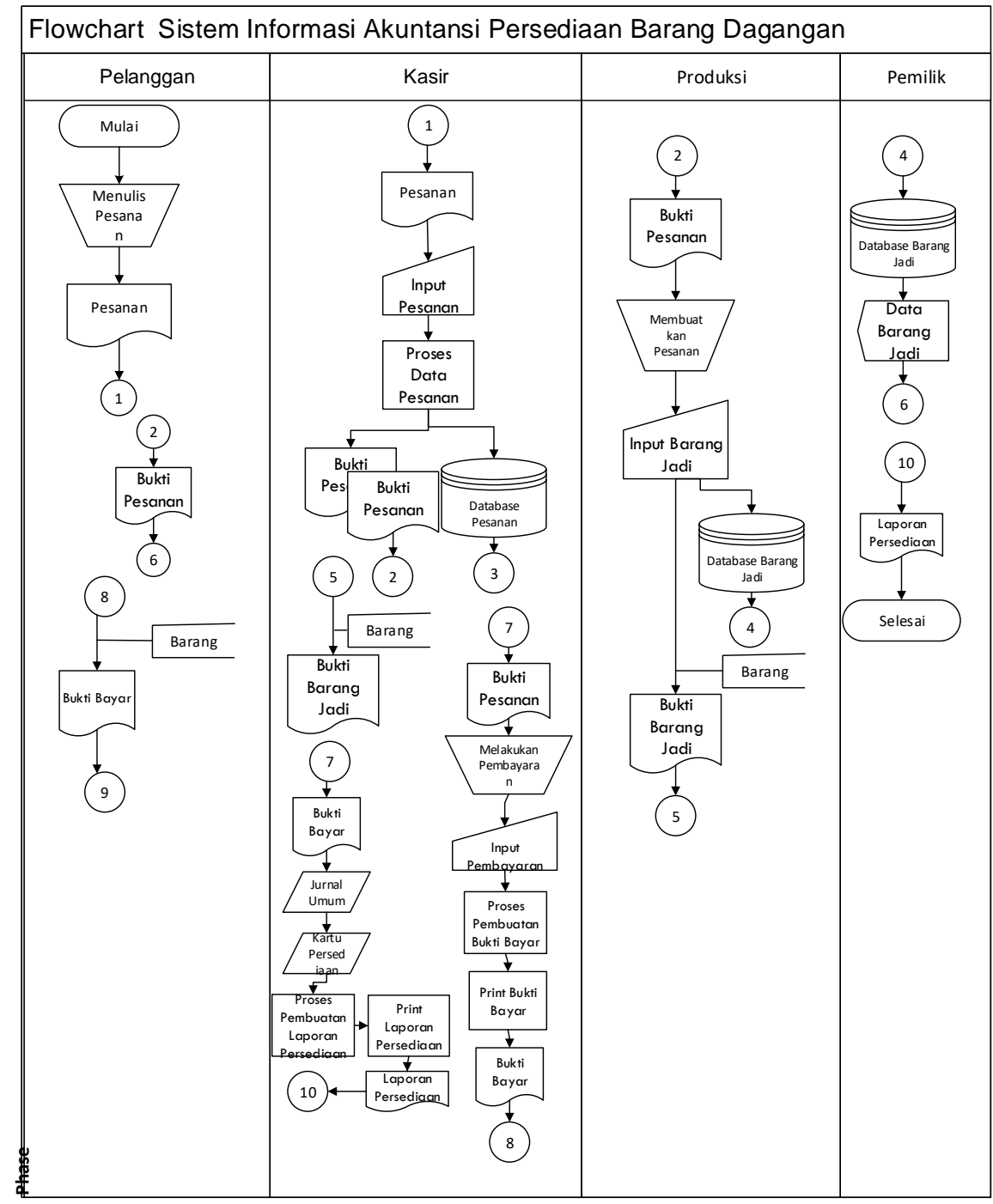

Gambar 5. Flowchart Sistem yang diusulkan 
Gambar 5 adalah flowchart yang diusulkan untuk sistem yang akan dibuat dimana ada 4 entitas yaitu pelanggan, kasir, produksi, dan pemilik. Masing masing memiliki tugas masing masing dalam sistem itu sendiri.

3. ERD(Entity Relationship Diagram)

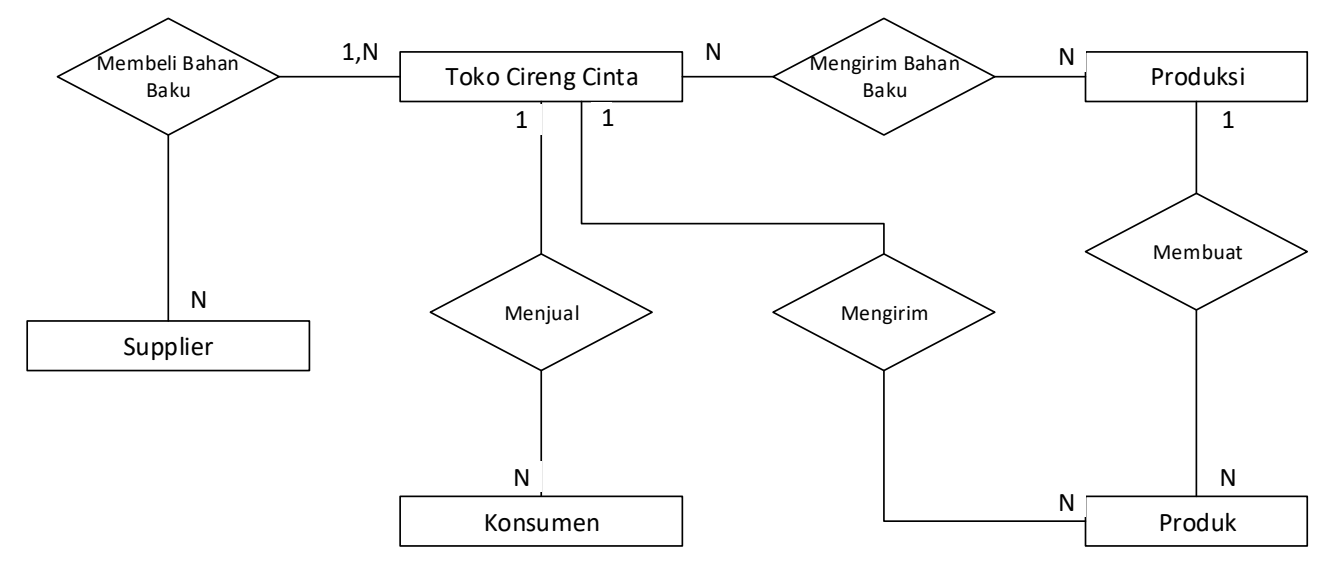

Gambar 6. ERD

Gambar 6 adalah penjelasan dari ERD dalam sistem ini dan menjelaskan alur hubungan dari mulai supplier sampe dengan konsumen.

4. Diagram Konteks dan Data Flow Diagram

4.1 Diagram Konteks

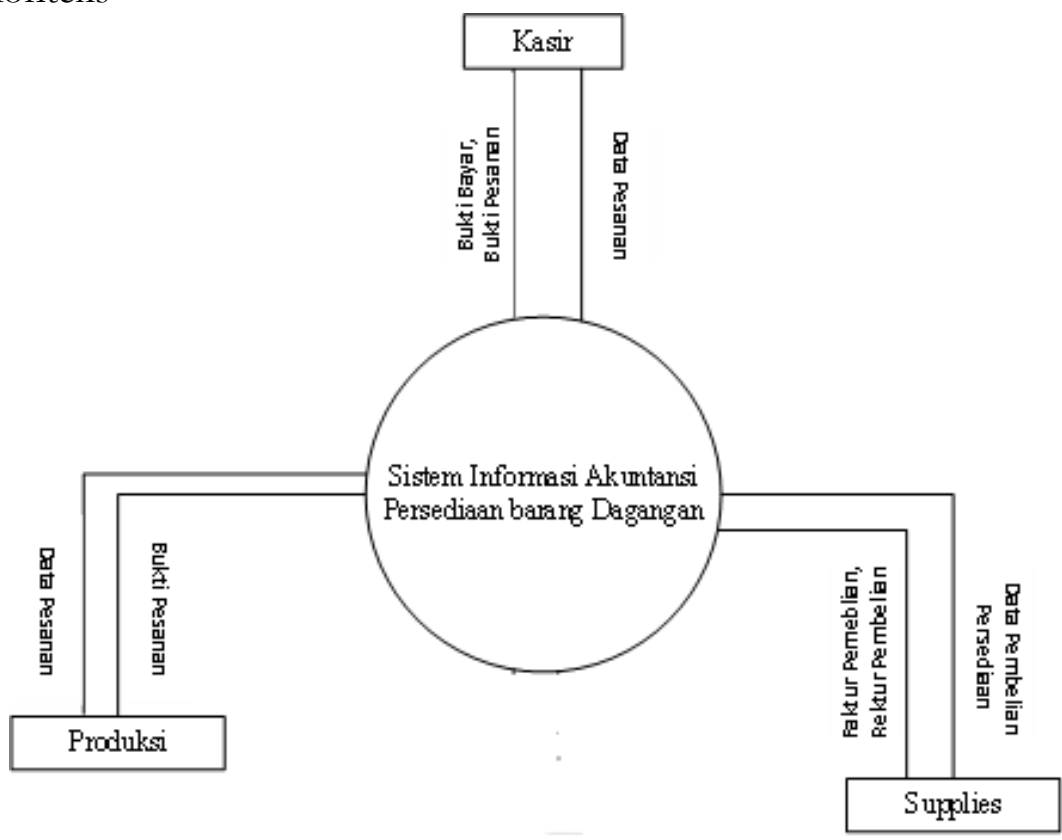

Gamabr 7. Diagram Konteks

Gambar 7 adalah Diagram Konteks yang diusulkan dimana menjelaskan mengalirnya arus data dalam sistem yang berjalan. Dimana dijelaskan untuk setiap entitasnya membawa dan memberi data apa sajah. 
4.2 Data Flow Diagram lvl 0

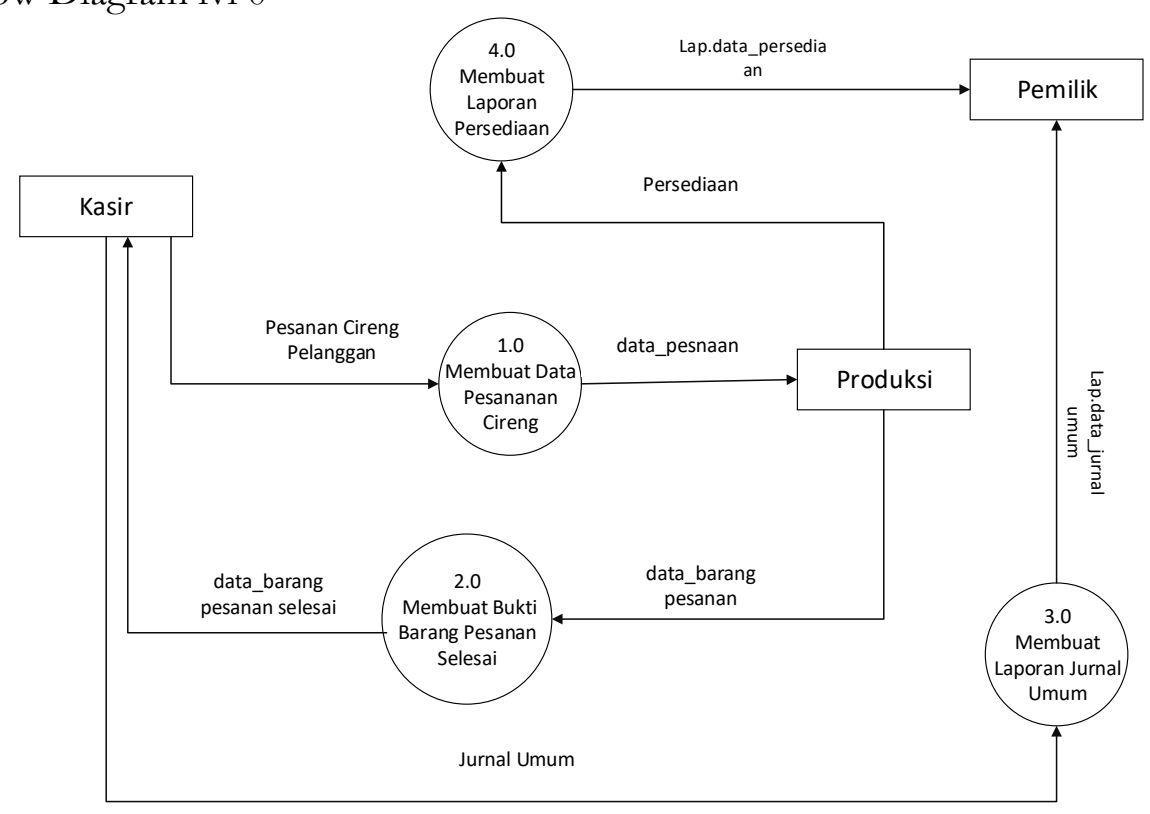

Gambar 8 DFD lv 0

Gambar 8 adalah DFD lv 0 dimana menjelaskan alur data yang terjadi pada sistem kepada setiap entitas yang terlibat didalamnya. Dan penjelasan lebih lanjut dari Diagram kontek dimana lebih mendetail jalannya setiap data dalam sistem tersebut.

5. User Interface

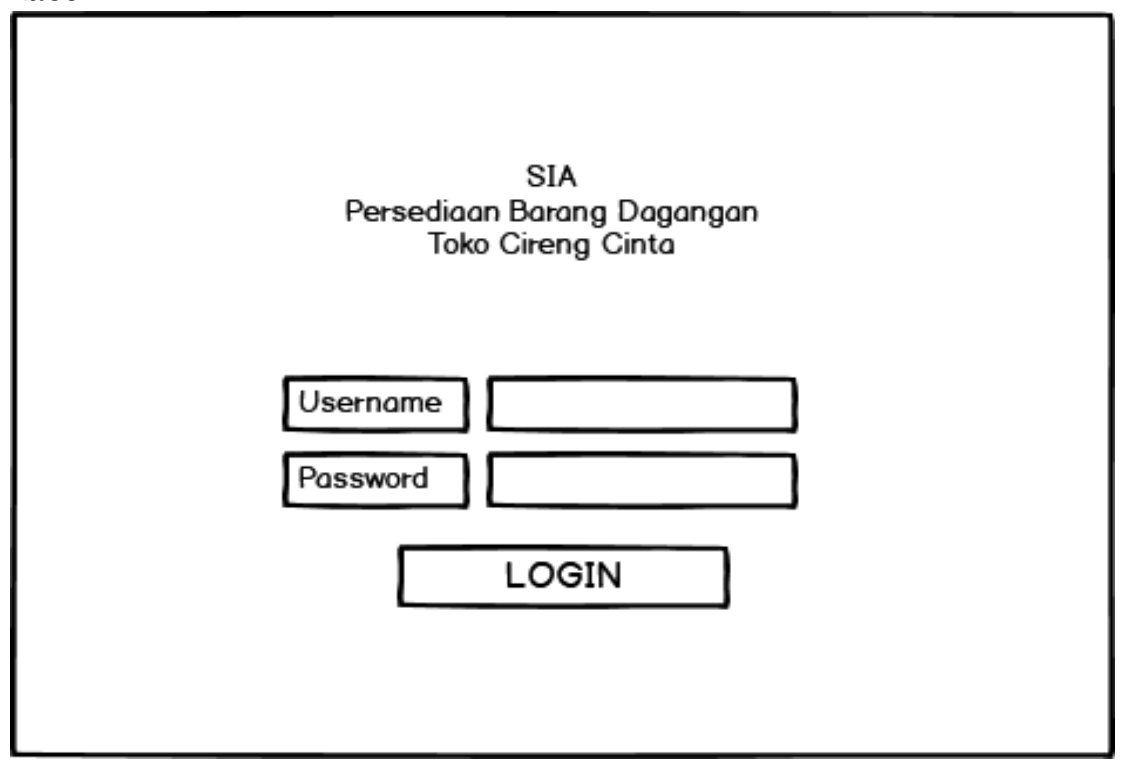

Gambar 9 Menu Login

Gambar 9 adalah tampilan meu login dimana setiap user memasukan username dan password yang dimiliki, dan login ini terdiri untuk kasir, bagian produksi, dan pemilik. 


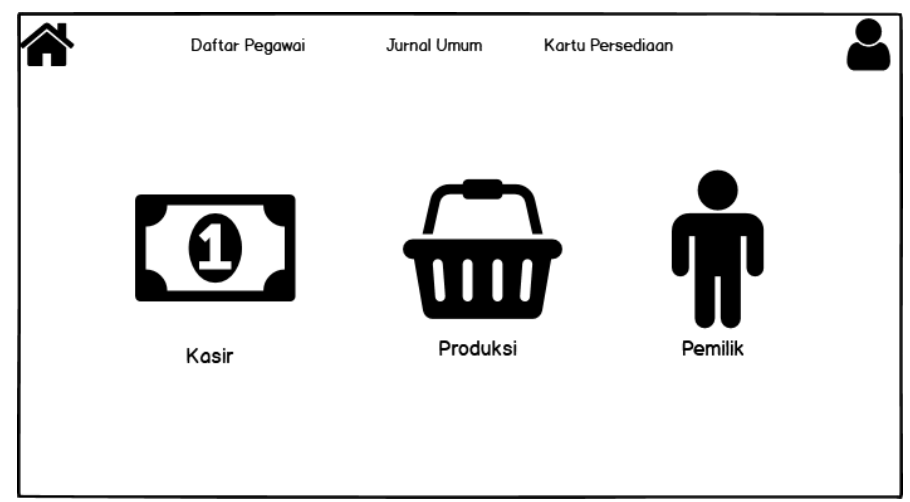

Gambar 10 Menu Utama

Gambar 10 adalah menu utama, dimana ada tombol home, daftar pegawai, jurnal umum, kartu persediaan, profile, kasri,produksi,dan pemilik. Dimana setiap setelah login makan masing masing bagian hanya bisa mengklik satu di antara tiga entitas yang ada. Kemudian di daftar pegawai nanti bisa melilhat list daftar pegawai, untuk jurnal umum bisa melihat jurnal yang telah diinput oleh kasir, dan kartu persediaan bisa melihat persediaan-persediaan yang telah diinput oleh bagian produksi.

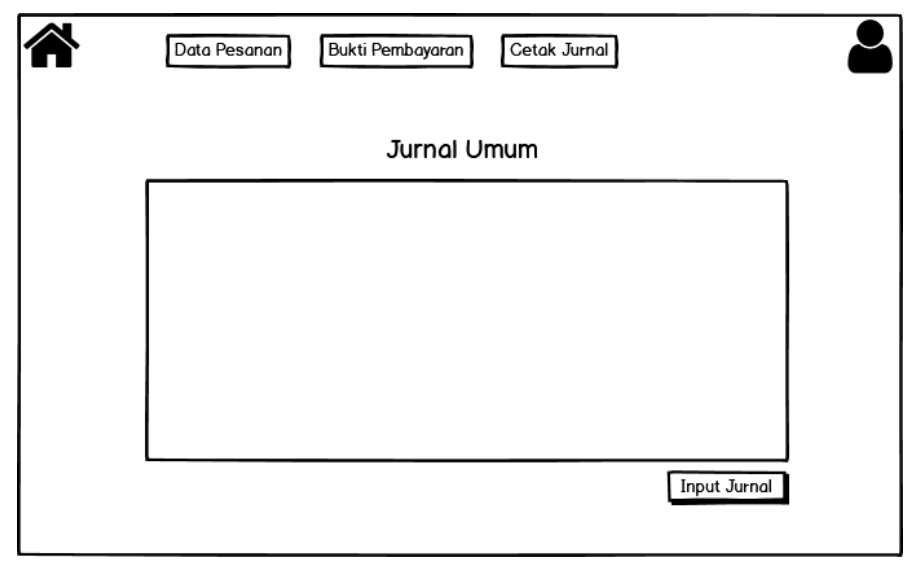

Gambar 11 Menu Kasir

Gambar 11 adalah menu utama kasir, dimana bisa menginput jurnal, membuat data pesanan, bukti pembayaran, dan mencetak jurnal umum.

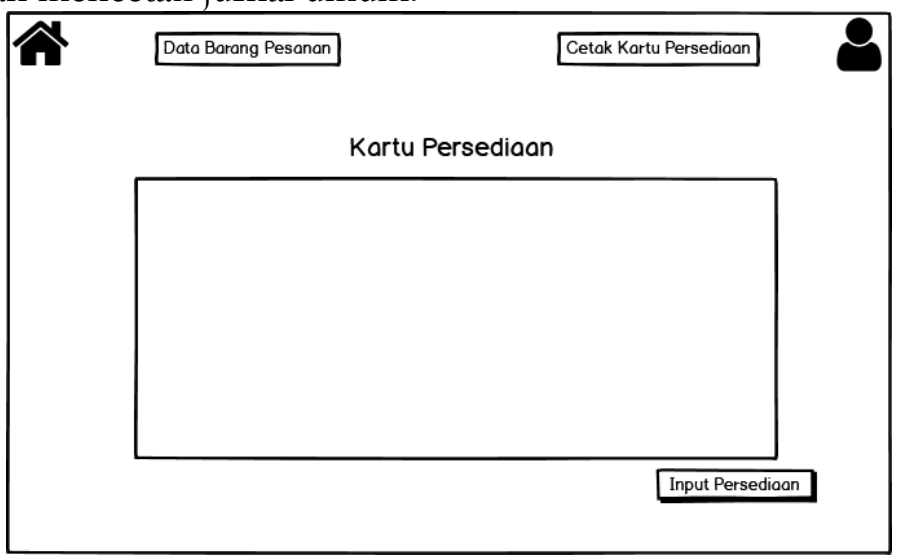

Gambar 12 Menu Produksi 
Gambar 12 adalah menu utama bagian produksi, dimana bisa menginput kartu persediaan, membuat data barang pesanan, dan mencetak kartu persediaan.

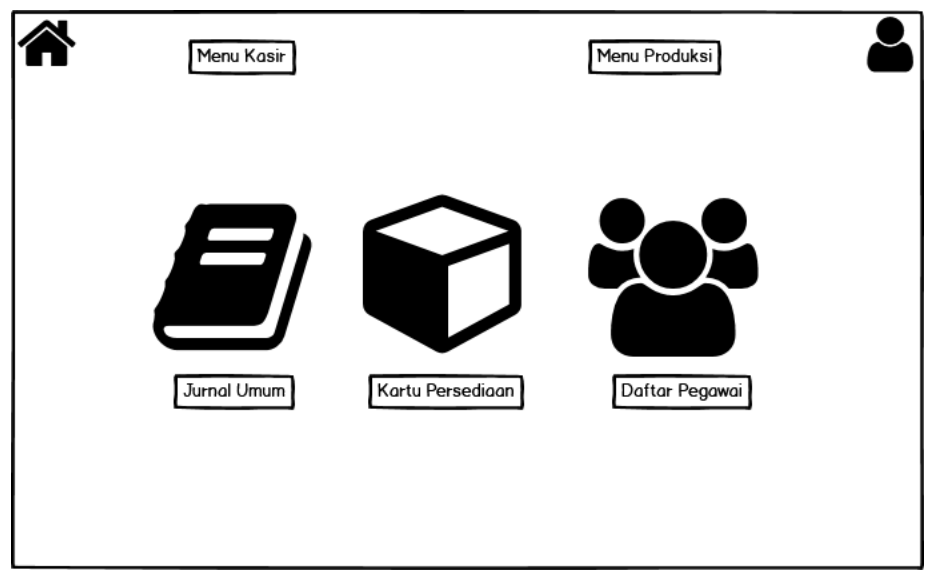

Gambar 13 Menu Pemilik

Gambar 13 adalah Menu utama pemilik dimana pemilik memiliki semua akses kesetiap entitas bisa melihat jurnal umum, kartu persediaan, dan menambah daftar pegawai. Kemudian bisa mengakses ke bagian kasir dan produksi bila diperlukan.

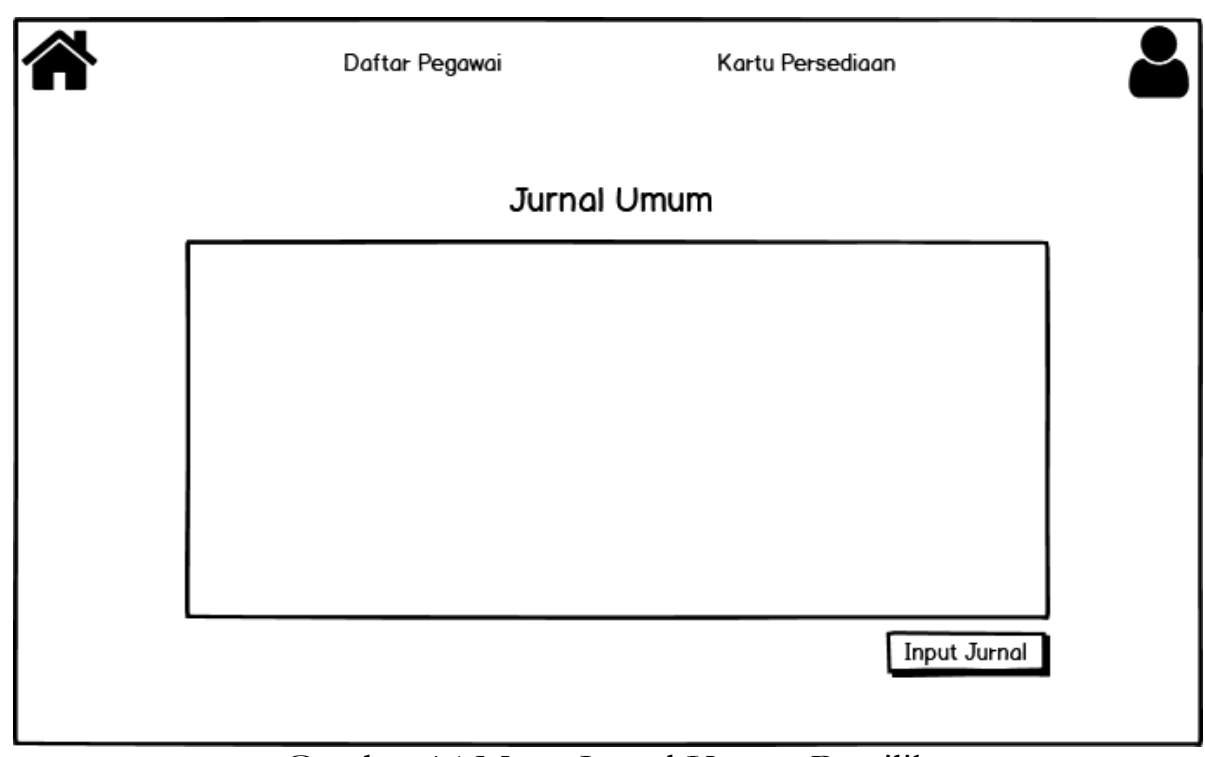

Gambar 14 Menu Jurnal Umum Pemilik

Gambar 14 adalah lanjutan dari gambar 13 dimana jika pemilik mengklik jurnal umum maka akan muncul tampilan jurnal umum, dan bisa menginput atau mengedit bila ada kesalahan yang terjadi oleh kasir atau hanya sekedar melihat jurnal umum. 


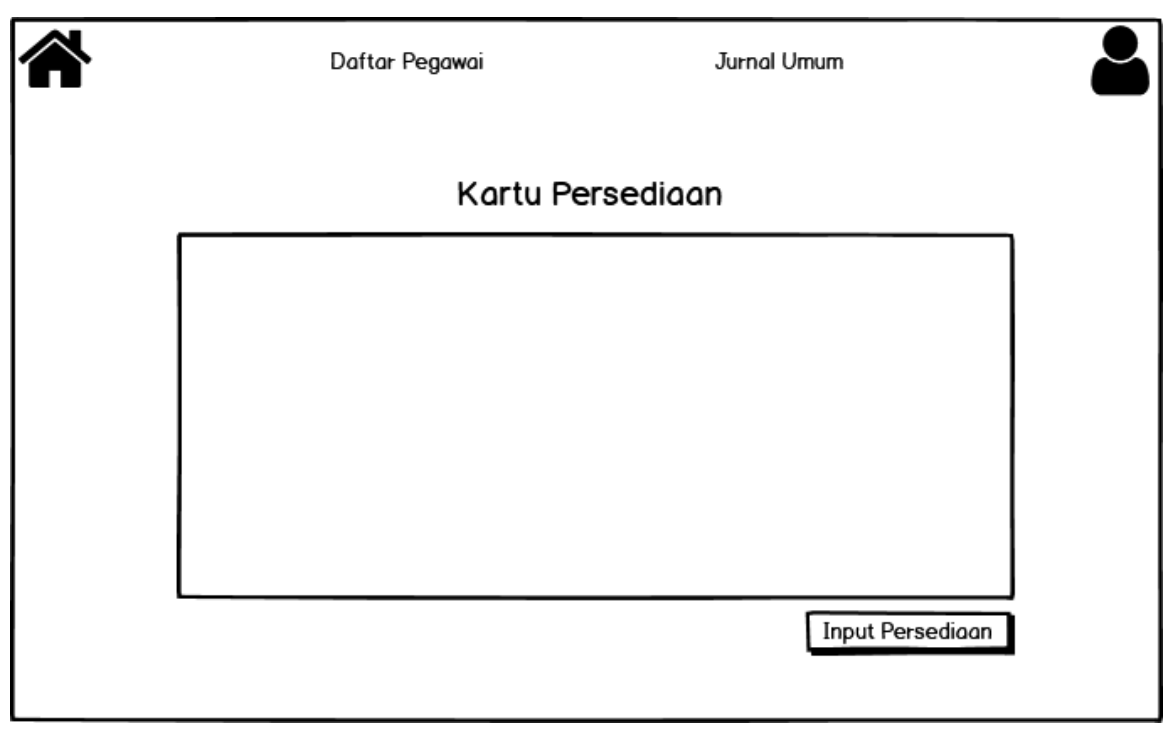

Gambar 15 Menu Kartu Persediaan Pemilik

Gambar 15 adalah lanjutan dari gambar 14 dimana jika pemilik mengklik kartu persediaan maka akan muncul tampilan kartu persediaan, dan bisa menginput atau mengedit bila ada kesalahan yang terjadi oleh bagian produksi atau hanya sekedar melihat kartu persediaan.

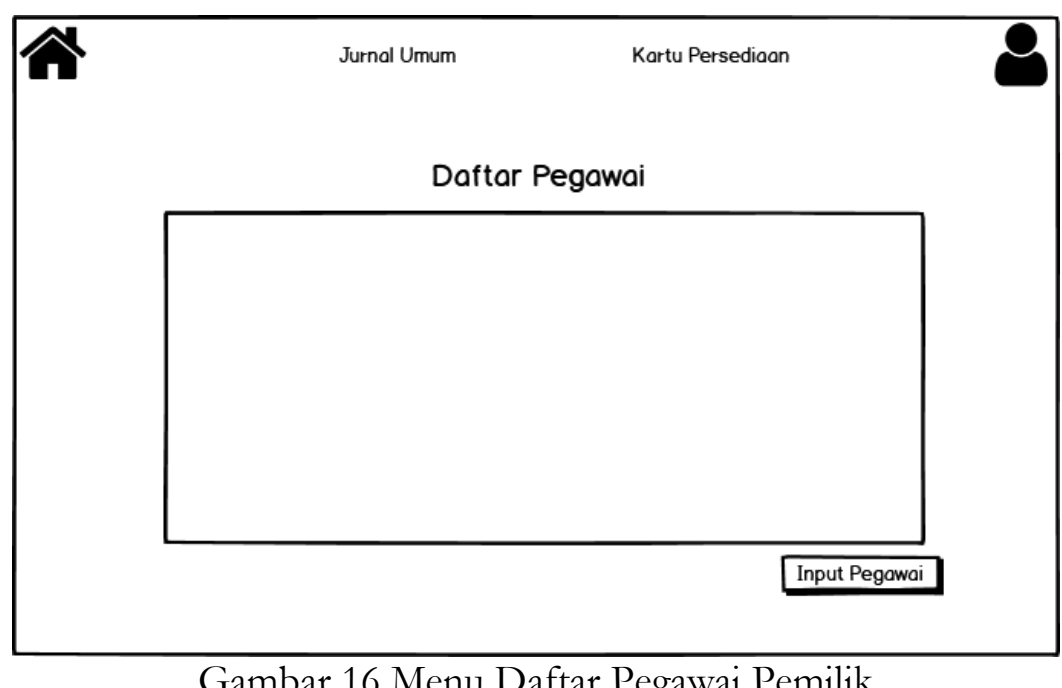

Gambar 16 Menu Daftar Pegawai Pemilik

Gambar 16 adalah lanjutan dari gambar 15 dimana jika pemilik mengklik daftar pegawai maka akan muncul tampilan daftar pegawai, dan bisa menginput atau mengedit bila ada pegawai atau hanya sekedar melihat daftar pegawai.

\section{Penutup}

Rancangan sistem akuntansi informasi persediaan barang dagangan ini makan akan memumdahkan pengembangan aplikasinya selanjutnya. Dari proses input dan pengolahan persediaan juga untuk memudahkan membuat jurnal dan bukti- bukti lainnya. Untuk pengembangan aplikasi berbasis online diharapkan memudahkan bagi pemilik untuk mengembangkan usaha kedepannya. Dalam penelitian ini juga menghasilkan rancangan berupa Flowchart, Diagram Konteks dan Data Flow Diagram, Entity Relationship Diagram, dan User Inteface. Dengan rancangan sistem ini bisa memudahkan pengembangan aplikasi yang sudah sesuai 
dengan SAK EMKM dari transaksi sampai pencatatan jurnal umum, buku besar, kartu persediaan, laporan persediaan barang dagang, dan laporan arus kas.

\section{Daftar Pustaka}

[1] V. Barhatov, A. Campa, and P. D, "The Impact of Internet-Technologies Development on Small Business Success in Russia," Procedia - Soc. Behav. Sci., vol. 238, pp. 552-561, 2018.

[2] Lilis Puspitawati, Sri Dewi Anggadini. 2011. Sistem Informasi Akuntansi. Jakarta.Graha Ilmu.

[3] S. Priharjanto, M. Sarma, and S. Hartoyo, "Kelayakan dan Strategi Pengembangan Usaha Makanan Ringan Pada PD Sinar Berlian di Jakarta Barat," J. Manaj. Pengemb. Ind. Kecil Menengah, vol. 7, no. 2, pp. 122-130, 2012.

[4] E. P. Ongkorahardjo, "FORMULASI STRATEGI USAHA MAKANAN RINGAN TRADISIONAL NY. GAN DI SURABAYA," AGORA, vol. 3, no. 2, pp. 665-674, 2015.

[5] H. Gebauer, A. Gustafsson, and L. Witell, "Competitive advantage through service differentiation by manufacturing companie," J. Bus. Res., vol. 64, no. 12, pp. 1270-1280, 2011.

[6] S. J. A. N. bin S. Mohamad, N. N. Suraidi, N. A. A. Rahman, and R. D. S. R. Suhaimi, "A Study on Relationship between Inventory Management and Company Performance: A Case Study of Textile Chain Store," J. Adv. Manag. Sci., vol. 4, no. 4, pp. 299-304, 2016.

[7] R. Nur and M. A. Suyuti, Pengantar Sistem Manufaktur. Yogyakarta: DEEPUBLISH, 2017.

[8] D. W. Firdaus and S. Febryan, "Perancangan Sistem Informasi Akuntansi Harga Pokok Produksi Pada Distro Viking Cimahi Dengan Menggunakan Software Microsoft Visual Basic 2008 Dan Database MySQL,” @is Best Account. Inf. Syst. Inf. Technol. Bus. Enterp., vol. 4, no. 1, pp. 366-380, 2019.

[9] T. Sutarbi, Analisis Sistem Informasi. Yogyakarta: Andi Offset, 2012.

[10] A. Maryono, Pola Pikir Sistem. Yogyakarta: Gadjah Mada University Press, 2014.

[11] S. Mulyani, Metode Analisis dan Perancangan Sistem. Abdi Sistematika, 2017.

[12] Yakub, Pengantar Sistem Informasi. Graha Ilmu, 2012.

[13] J. Hutahaean, Konsep Sistem Informasi. Yogyakarta: DEEPUBLISH, 2014.

[14] P. Pirmansah and H. D. Yulianto, "Perancangan Sistem Informasi Akuntansi Persediaan Barang Dagang (Sparepart) dengan Menggunakan Software Microsoft Visual Basic 2005 dan SQL Server 2005 Berbasis Client Server pada CV. Ahass Bintang Firdaus Motor," @is Best Account. Inf. Syst. Inf. Technol. Bus. Enterp., vol. 2, no. 2, pp. 186-203, 2017.

[15] T. Rahmasari, "Perancangan Sistem Informasi Akuntansi Persediaan Barang Dagang Pada Toserba Selamat Menggunakan Php Dan Mysql," @is Best Account. Inf. Syst. Inf. Technol. Bus. Enterp., vol. 4, no. 1, pp. 411-425, 2019.

[16] F. Zamzami and N. Duta, Akuntansi Pengantar 1. Yogyakarta: Gadjah Mada University Press, 2016.

[17] Supriyati and R. S. Bahri, "Model Perancangan Sistem Informasi Akuntansi Laporan Keuangan Pondok Pesantren Berbasis SAK ETAP," @is Best Account. Inf. Syst. Inf. Technol. Bus. Enterp., vol. 4, no. 2, pp. 151-165, 2019.

[18] D. Darwis, F. D. Apriyanti, and E. R. Susanto, "PERANCANGAN SISTEM INFORMASI AKUNTANSI PENGELUARAN OPERASIONAL PERUSAHAAN (STUDY KASUS : PT SARI SEGAR HUSADA)," J. TEKNOKOMPAK, vol. 13, no. 1, pp. 1-6, 2019.

[19] Supriyati, Pengantar Akuntansi. Bandung: Labkat Press UNIKOM, 2013.

[20] Mulyadi, Akuntansi Biaya, 5th ed. Yogyakarta: Unit Penerbit dan Percetakan Sekolah Tinggi Ilmu Manajemen YKPN, 2015.

[21] I. A. Indonesia, "Standar Akuntansi Keuangan Entitas Mikro Kecil dan Menengah (EMKM)." [Online]. Available: Standar Akuntansi Keuangan Entitas Mikro Kecil dan 
Menengah (EMKM). [Accessed: 11-May-2020].

[22] M. R. Aryanti, Purwanto, and Suharyadi, "Perancangan Sistem Informasi Akuntansi Penerimaan Kas (Studi Kasus: Koperasi Kota Salatiga)," @is Best Account. Inf. Syst. Inf. Technol. Bus. Enterp., vol. 04, no. 01, pp. 121-135, 2019. 